\title{
Incidence of Methicillin-Resistant Staphylococci in Fresh Seafood
}

\author{
Lekshmi R. G. Kumar, Anas K. Kasim, Manjusha Lekshmi, Binaya Bhusan Nayak, \\ Sanath Kumar* \\ QC Laboratory, Post Harvest Technology Department, ICAR-Central Institute of Fisheries Education (CIFE), \\ Mumbai, India \\ Email: "sanathkumar@cife.edu.in
}

Received 6 February 2016; accepted 7 May 2016; published 11 May 2016

Copyright (C) 2016 by authors and Scientific Research Publishing Inc.

This work is licensed under the Creative Commons Attribution International License (CC BY). http://creativecommons.org/licenses/by/4.0/

c. (i) Open Access

\begin{abstract}
The occurrence of methicillin-resistant staphylococci was investigated in fresh seafood, seafood products and related samples. Staphylococci were isolated from $13(68.42 \%)$ fresh seafood samples, while $3(15.78 \%)$ samples harbored coagulase-positive $S$. aureus. Resistance to methicillin was observed in 16 isolates of Staphylococcus spp., 15 of which were coagulase-negative $S$. aureus (MR-CoNS) and one was a coagulase-positive S. aureus (MRSA). The mecA gene is detected by PCR in $10 \mathrm{MR}$-CoNS and one MRSA strain. The ImrS gene, which codes for a multidrug efflux pump LmrS, is detected only in coagulase-positive isolates.
\end{abstract}

\section{Keywords}

Seafood, MRSA, CoNS, mecA, Staphylococcus

\section{Introduction}

Staphylococcus aureus, an opportunistic bacterial pathogen commonly associated with asymptomatic colonization of skin and the mucosal surfaces of humans and animals, is one of the leading causes of food-borne illnesses in humans [1] [2]. Food poisonings due to S. aureus occur when foods containing one or more preformed staphylococcal enterotoxins (SEs) are ingested. S. aureus is also responsible for many of the nosocomial infections and community acquired diseases [3]. Emergence of $S$. aureus as a serious pathogen is attributed to its intrinsic virulence and the capacity to adapt to different environmental conditions and also by virtue of its ability to develop or acquire resistance to almost any new antimicrobials [4] [5]. The antibiotic resistance of $S$. aureus has become a major concern following the emergence of MRSA (methicillin-resistant S. aureus) and CA-MRSA

"Corresponding author.

How to cite this paper: Kumar, L.R.G., Kasim, A.K., Lekshmi, M., Nayak, B.B. and Kumar, S. (2016) Incidence of MethicillinResistant Staphylococci in Fresh Seafood. Advances in Microbiology, 6, 399-406.

http://dx.doi.org/10.4236/aim.2016.66039 
(community-acquired MRSA) [6]. In addition to MRSA, methicillin-resistant coagulase-negative staphylococci (MR-CoNS) are increasingly being recognized as causative agents of nosocomial infections [7]. MRSA have been found in farms and food animals [8], meat [9] [10], milk [11] and poultry [12]. Livestock workers and meat handlers are at particular risk of being colonized by livestock-associated MRSA (LA-MRSA) [13]. Certain lineages of MRSA, such as the type (ST) 398, spa type t108, are capable of human to human transmission or animal to human transmission [14]. Freshly caught seafood is free from S. aureus [15], hence their presence on fish is a clear indication of secondary contamination during transport and handling [16]. MRSA is introduced into foods by food handlers who are carriers of this bacterium or contamination by other foods which harbor MRSA. Past studies have reported the occurrence of antibiotic-resistant S. aureus in fresh seafood [17], ready-to-eat fish [18], seafood products [19] and also in cultured fish [20]. In this study, we sought to determine the prevalence of methicillin-resistant staphylococci in fresh seafood, fish products, seafood processing equipment and the sea salt used in fish fermentation. The results of this study show that MR-CoNS are more dominant than the MRSA in fresh seafood. This is the first report on the incidence of methicillin-resistant staphylococci in fresh seafood in India.

\section{Materials and Methods}

\subsection{Sampling}

Thirty-five samples were processed for the isolation of Staphylococcus spp. which included seafood samples from retail markets and landing centers in North Mumbai, fish products, salt, seawater and surface swabs. Sterile swabs were used to collect duplicate swab samples from the surfaces of processing equipment such as the silent cutter, mixer, extruder as well as the pre-processing table in the fish processing unit of the institute where this study was conducted. Moistened swabs were rolled multiple times on the surfaces and rinsed in sterile saline followed by spread plating of 0.4, 0.3 and $0.3 \mathrm{ml}$ of suspension on Baird Parker agar.

\subsection{Isolation and Identification of $S$, aureus}

Twenty-five grams of the sample (fresh fish or fish products) was aseptically weighed and mixed with $225 \mathrm{~mL}$ tryptone water and homogenized for 60 seconds in a stomacher (Seward Stomacher 80, Lab system, London, UK). The homogenate was serially diluted with sterile saline (1:10 dilution). From each dilution, aliquots of 0.4, 0.3 and $0.3 \mathrm{ml}$ each were spread plated on Baird-Parker agar (BPA) supplemented with 3.5\% egg yolk-tellurite emulsion [21]. Colonies typical of Staphylococcus spp. picked from BPA plates were Gram stained and identified by biochemical tests, which included catalase test, glucose and mannitol fermentation tests and sensitivity to novobiocin. The coagulase production was determined by coagulase test using rabbit serum (Hi-Media, Mumbai, India).

\subsection{Antibiotic Resistance Tests}

The methicillin-resistance phenotype of staphylococci was determined by standard disc diffusion method on Mueller-Hinton agar (Hi-Media, Mumbai, India) using oxacillin $(1 \mu \mathrm{g})$ andcefoxitin (30 $\mu \mathrm{g})$. The plates were incubated at $35^{\circ} \mathrm{C}$ for $24 \mathrm{~h}$. A total of 199 isolates, comprising of 4 coagulase-positive $S$. aureus and 195 CoNS, were included in the test. The results of antibiotic susceptibility test were interpreted as per guidelines of CLSI for S. aureus and CoNS [22].

\subsection{Oligonucleotide Primers and PCR}

Oligonucleotide primers specific for Staphylococcus genus-specific 16S rDNA gene, S. aureus species specific femA gene (encoding a factor responsible for methicillin resistance) and the nucA gene (encoding a thermonuclease), methicillin-resistance gene mecA and the lincomycin efflux gene $\operatorname{lmrS}$ were used to in the PCR assays (Table 1). DNA of Staphylococcus aureus ATCC BAA-976) was used as the positive control in all PCR reactions. The thermocycling conditions for the amplifications of 16S rDNA, femA, nuc and mecA genes were same as previously described [23]-[25]. For the amplification of $\operatorname{lmrS}$ gene using the primers designed in this study, the thermocycling conditions consisted of 1 min denaturation at $94^{\circ} \mathrm{C}, 1$ min annealing at $55^{\circ} \mathrm{C}$ and 1 min extension at $72^{\circ} \mathrm{C}$. The products of PCR were electrophoresed on $1.6 \%$ agarose gel, stained with ethidium bromide and photographed using a gel documentation system (Bio-Rad, Hercules, USA) 
Table 1. Oligonucleotide primers used.

\begin{tabular}{|c|c|c|c|}
\hline Primer & Nucleotide sequence (5’-3’) & Product size (bp) & Reference \\
\hline 16S rDNA & $\begin{array}{l}\text { gcaagcgttatccggattt } \\
\text { cttaatgatggcaactaagc }\end{array}$ & 599 & 25 \\
\hline femA & $\begin{array}{l}\text { cgatccatatttaccatatca } \\
\text { atcacgctcttcgtttagtt }\end{array}$ & 454 & 25 \\
\hline nuc & $\begin{array}{c}\text { gcgattgatggtgatacggtt } \\
\text { agccaagccttgacgaactaaagc }\end{array}$ & 270 & 23 \\
\hline mecA & $\begin{array}{l}\text { actgctatccaccctcaaac } \\
\text { ctggtgaagttgtaatctgg }\end{array}$ & 163 & 24 \\
\hline $\operatorname{lm} r S$ & $\begin{array}{l}\text { aaatggtactcgccaactcg } \\
\text { tggcgtcatgatacctctga }\end{array}$ & 241 & This study \\
\hline
\end{tabular}

\section{Results}

Different sample types analyzed in this study yielded Staphylococcus spp. (Table 2). Among seafood samples, staphylococci were isolated from 10 of 14 fish samples and 3 of 5 shellfish samples, for an overall prevalence rate of $68.42 \%$. Of various seafood products, 3 of the 10 products yielded staphylococci. These products included breaded and battered tuna, fish sausage and fish pickle. A total of 199 isolates were confirmed to be Staphylococcus spp. by biochemical tests as well as by the genus-specific 16S rDNA PCR. When different samples were compared, the highest incidence of Staphylococcus spp. was found in fish samples followed by fish products and shellfish (Table 2). Of the 4 swab samples collected from the fish processing unit, 3 samples yielded Staphylococcus spp. The coagulase-positive $S$. aureus were found in 4 samples of which 3 were fish samples and one was a sample of sea salt used in fish fermentation. These isolates were identified by $S$. aureus-specific PCRs amplifying nucA and femA genes. The coagulase-positive S. aureus were isolated from fresh Tenulosailisha, Coilia dussumieri and dried Harpadon nehereus (Bombay duck).

Both coagulase-positive $S$. aureus and coagulase-negative Staphylococcus spp. were tested for methicillin resistance phenotype. The different sample types that yielded methicillin-resistant staphylococci are shown in Table 3. Of the 199 isolates of Staphylococcus spp. tested, 16 isolates from 9 samples were resistant to oxacillin/ cefoxitin, of which 1 was a coagulase-positive $S$. aureus. This particular $S$. aureus was isolated from the salt. The remaining $3 \mathrm{~S}$. aureus isolates were sensitive to methicillin. The mecA gene, which encodes penicillinbinding protein PBP2a, was detected by PCR in 10 methicillin-resistant coagulase-negative staphylococci (MRCoNS) and one MRSA isolate. Five MR-CoNS isolates were negative for mecA gene. The $\operatorname{lmrS}$ gene was detectable in 4 coagulase-positive $S$. aureus isolates, one of which was a MRSA. None of the MR-CoNS carried the $\operatorname{lm} r S$ gene (Figure 1).

\section{Discussion}

Several factors such as poor hygiene and sanitation during seafood handling and transportation, cross-contamination during storage and contamination by workers who are asymptomatic carriers of coagulase-positive $S$. $a u-$ reus contribute to the introduction of $S$. aureus into the seafood. Many studies have shown that $S$. aureus could be present in fresh seafood, ready-to-cook and ready-to-eat seafood products, seafood processing environments and the hands of seafood handlers [26]-[32]. In our study, a total of 35 random samples were analyzed for the presence of Staphylococcus spp. and the bacterium was isolated from 20 samples. Coagulase-positive S. aureus were found in 4 samples, of which 3 were fresh fish samples and one was a sample of salt used in fish fermentation (Table 2). The occurrence of coagulase-positive S. aureus in fresh seafood is $15.78 \%$ (3 of 19 samples). Different studies have recorded varying rates of $S$. aureus isolation from seafood. Normanno et al. [33] reported a low isolation rate of $2.3 \%$ from fish products, whereas a higher incidence of $20 \%$ was reported in fresh seafood harvested in the southern region of Brazil [27]. A recent study by Zarei et al. [34] detected S. aureus in 5\% of the raw/fresh samples of fish and shrimp, $17.5 \%$ of the frozen, and $12.3 \%$ of the RTE samples marketed in Iran. A relatively high incidence of $S$. aureus has also been reported from Spain in which $S$. aureus was found in $43 \%$ of fresh fish and $30 \%$ of frozen products [28]. A pervious study from India has reported that $17 \%$ of the fishery products and $62 \%$ of the samples from the factory workers were positive for enterotoxigenic S. aureus [32]. However, this high prevalence rate was found in frozen peeled shrimps and cuttlefish which were subjected 
Table 2. Occurrence of Staphylococcus spp. in different sample types.

\begin{tabular}{cccc}
\hline Sample type & No. of samples analyzed & No. positive for staphylococci & No. positive for S. aureus \\
\hline Fish & 14 & 10 & 3 \\
Shellfish & 5 & 3 & - \\
Fishery products & 10 & 3 & - \\
Fish processing environment & 4 & 3 & 1 \\
Salt & 1 & 0 & 4 \\
Seawater & 1 & 20 & 4 \\
Total & 35 & &
\end{tabular}

Table 3. Distribution of methicillin-resistant staphylococci in samples analyzed in this study. The methicillin resistance was determined using oxacillin $(1 \mu \mathrm{g})$ and cefoxitin $(30 \mu \mathrm{g})$ disks.

\begin{tabular}{|c|c|c|}
\hline Samples & No. of isolates tested & No. resistant to methicillin \\
\hline Coilia dussumieri & 7 & 0 \\
\hline Tenulosa ilisha & 4 & 0 \\
\hline Epinephelus diacanthus & 7 & 0 \\
\hline Nemipterus japonicus & 3 & 0 \\
\hline Muraenoscox cinereus & 2 & 0 \\
\hline Harpadon nehereus & 2 & 0 \\
\hline Pampus argenteus & 31 & 5 \\
\hline Trichiurus lepturus & 14 & 0 \\
\hline Tachysaurus dussumieri & 20 & 1 \\
\hline Dried Harpadon nehereus (Bombay duck) & 4 & 0 \\
\hline Metapenaeus dobsoni & 4 & 2 \\
\hline Meretrix meretrix & 7 & 1 \\
\hline Loligo duvacelli & 9 & 0 \\
\hline Fish sausage & 15 & 1 \\
\hline Battered and breaded tuna & 24 & 3 \\
\hline Fermented Indian mackerel (Rastrelliger kanagurta) & 34 & 1 \\
\hline Salt & 1 & $1^{\mathrm{a}}$ \\
\hline Swabs from silent cutter & 4 & 1 \\
\hline Swabs from extruder & 7 & 0 \\
\hline Swabs from pre-processing table & 1 & 0 \\
\hline Total & 199 & 16 \\
\hline
\end{tabular}

to extensive handling at various stages of processing leading to higher levels of contamination.

In our study, coagulase-positive $S$. aureus was isolated from a sample of salt used in fish fermentation and preparation of fish products in our institutional facility. S. aureus is a common contaminant of salt since it can tolerate low water activity. When such salt is used in the preparation of salted fish or other fish products, $S$. aureus is introduced into the products [35]. Isolation of $S$. arlettae in large numbers from salted cod has been reported and this species was found to be extremely halotolerant, being able to grow from $0.06 \mathrm{M}-4.5 \mathrm{M} \mathrm{NaCl}$ [36]. High prevalence of $S$. aureus has been reported in salted fish, smoked and salted fish, and salted and cold smoked fish [19] [37] [38]. S. aureus is a known halotolerant organism, being able to grow at salt concentrations 


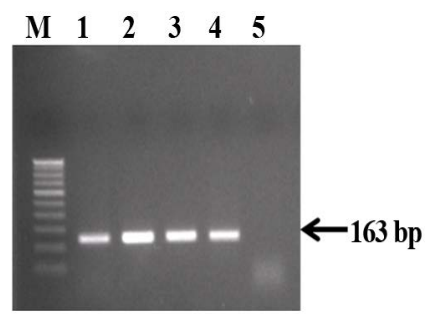

Figure 1. Detection of $\operatorname{lmrS}$ gene in seafood isolates of coagulase-positive $S$. aureus. Lane M, Gene Ruler $1 \mathrm{~kb}$ DNA ladder (Fermentas); Lane 1, Positive control $S$. aureus BAA-976; Lane 2, isolate from salt; Lanes 3 \& 4, isolates from fish; Lane 5, negative control.

of $7 \%-10 \%$, with some strains being able to withstand a $\mathrm{NaCl}$ concentration as high as $20 \%$ [39]. In salted sardines, S. aureus was reportedly able to survive for up to 90 days [40]. However, a literature search did not yield any information on the isolation of $S$. aureus directly from the salt. Nevertheless, the isolation of toxigenic $S$. aureus from an additive used in the preparation of fish products assumes significance. It is important to ensure that good quality raw materials and additives are used in the preparation of fishery products to prevent the spread of toxigenic $S$. aureus in general, and methicillin-resistant $S$. aureus in particular, since the isolate from salt in this study was found to be a MRSA.

A total of 199 isolates were identified as Staphylococcus spp. by 16S rDNA PCR. Of these, 4 coagulase-positive isolates were confirmed to be $S$. aureus by thermonuclease gene (nucA)-specific PCR. We also used a previously described PCR method amplifying femA gene to discriminate coagulase-positive $S$. aureus from CoNS [41]. The product of femA gene is essential for the expression of methicillin resistance in S. aureus and this gene has been reported to be a marker for $S$. aureus. All coagulase-negative staphylococci (CoNS) of this study were negative for femA.

Both MRSA and MR-CoNS are recognized worldwide as zoonotic agents capable of causing serious human infections and their presence in foods is a serious human health concern [42]-[44]. The focus of this study was also to understand the prevalence of MRSA and MR-CoNS in seafood. Based on cefoxitin and oxacillin resistance, a total of 16 isolates were found to be resistant to methicillin, of which one was a coagulase-positive $S$. aureus (Table 3). A PCR assay for mecA gene amplified the gene in 11 out of 16 isolates. Five MR-CoNS isolates were negative by mecA PCR. It is possible that the mecA-negative MR-CoNS may have a different mecA gene or a different mechanism of methicillin resistance altogether [45]-[47]. Some MR-CoNS isolated from sashimi were reported to be mecA negative [18]. Further, only $27.9 \%$ of the methicillin-resistant staphylococci were found to carry mecA gene by PCR [48]. Nevertheless, the presence of MRSA in seafood and seafood products is increasingly being reported creating health concern. MRSA have been isolated from fresh fish [49], cage cultured Tilapia [20] and the Japanese retail ready-to-eat raw fish (sashimi) [18] and other fishery products [17].

Efflux pumps are employed by bacteria to expel antimicrobial compounds including antibiotics out of the cell and protect themselves from their lethal effects [50] [51]. Such multidrug transporters can contribute significantly to bacterial multiple drug resistance (MDR), thus reducing the efficacy of chemotherapy. The genome of S. aureus contains more than 20 efflux pumps, majority of which are of the Major Facilitator Superfamily (MFS) type. MFS includes highly related secondary active and passive solute transporters, widely recognized as responsible for intrinsic and acquired antibiotic resistance in bacteria. Recently, Floyd et al. [52] described a multidrug efflux pump LmrS in an isolate of MRSA. LmrS can confer high antibiotic resistance to several antibiotics, the most prominent of them being lincomycin, fusidic acid, linezolid and erythromycin. However, not much is known about the distribution of this gene in Staphylococcus spp. We therefore wanted to determine whether $\operatorname{lmrS}$ is present in all S. aureus and CoNS and if it could be used as a genetic marker to detect $S$. aureus by PCR. The primers designed in this study detected $\operatorname{lmrS}$ in all 4 isolates of $S$. aureus, one of which was a MRSA (Figure 1). None of the CoNS was positive for the $\operatorname{lmrS}$ gene. These results are interesting and suggest that $\operatorname{lmrS}$ is limited to $S$. aureus, but is not a marker for methicillin resistance. Further studies are needed to understand if the isolates harboring $\operatorname{lmrS}$ are clonal and also if $\operatorname{lmrS}$ has any role in the physiology of survival of $S$. aureus in seafood, biofilm formation and even resistance to biocides used in fish processing plants. 


\section{Acknowledgements}

The authors thank Director, CIFE, Mumbai for helpful suggestions.

\section{References}

[1] Genigeorgis, C.A. (1989) Present State of Knowledge on Staphylococcal Intoxication. International Journal of Food Microbiology, 9, 327-360. http://dx.doi.org/10.1016/0168-1605(89)90100-1

[2] Zhang, S., Landolo, J. and Stewart, C. (1998) The Enterotoxin D Plasmid of Staphylococcus aureus Encodes a Second Enterotoxin Determinant (sej). FEMS Microbiology Letters, 168, 227-233. http://dx.doi.org/10.1111/j.1574-6968.1998.tb13278.x

[3] Holden, M.T., Feil, E.J., Lindsay, J.A., Peacock, S.J., Day, N.P.J., Enright, M.C., Foster, T.J., et al. (2004) Complete Genomes of Two Clinical Staphylococcus aureus Strains: Evidence for the Rapid Evolution of Virulence and Drug Resistance. Proceedings of the National Academy of Sciences of the United States of America, 101, 9786-9791. http://dx.doi.org/10.1073/pnas.0402521101

[4] Lowy, F.D. (1998) Staphylococcus aureus Infections. The New England Journal of Medicine, 339, 520-532. http://dx.doi.org/10.1056/NEJM199808203390806

[5] Waldvogel, F.A. (2000) Staphylococcus aureus (Including Staphylococcal Toxic Shock). In: Mandell, G.L., Bennett, J. E. and Dolin, R., Eds., Principles and Practice of Infectious Diseases, Churchill Livingstone, Philadelphia, 2069-2092.

[6] Chambers, H.F. (2005) Community-Associated MRSA-Resistance and Virulence Converge. The New England Journal of Medicine, 352, 1485-1487. http://dx.doi.org/10.1056/NEJMe058023

[7] Farrell, D.J. (1997) The Reliability of Microscan ${ }^{\mathrm{TM}}$ Conventional and Rapid Panels to Identify Staphylococcus aureus and Detect Methicillin Resistance: An Evaluation Using the Tube Coagulase Test and mecA PCR. Pathology, 29, 406-410. http://dx.doi.org/10.1080/00313029700169405

[8] Lee, J.H. (2003) Methicillin (Oxacillin)-Resistant Staphylococcus aureus Strains Isolated from Major Food Animals and Their Potential Transmission to Humans. Applied and Environmental Microbiology, 69, 6489-6494. http://dx.doi.org/10.1128/AEM.69.11.6489-6494.2003

[9] Boost, M.V., Wong, A., Ho, J. and O’Donoghue, M. (2013) Isolation of Methicillin-Resistant Staphylococcus aureus (MRSA) from Retail Meats in Hong Kong. Foodborne Pathogens and Disease, 10, 705-710. http://dx.doi.org/10.1089/fpd.2012.1415

[10] O’Brien, A.M., Hanson, B.M., Farina, S.A., Wu, J.Y., Simmering, J.E., Wardyn, S.E., Forshey, B.M., Kulick, M.E., Wallinga, D.B. and Smith, T.C. (2012) MRSA in Conventional and Alternative Retail Pork Products. PLoS ONE, 7, e30092. http://dx.doi.org/10.1371/journal.pone.0030092

[11] Haran, K.P., Godden, S.M., Boxrud, D., Jawahir, S., Bender, J.B. and Sreevatsan, S. (2012) Prevalence and Characterization of Staphylococcus aureus, including Methicillin-Resistant Staphylococcus aureus, Isolated from Bulk Tank Milk from Minnesota Dairy Farms. Journal of Clinical Microbiology, 50, 688-695. http://dx.doi.org/10.1128/JCM.05214-11

[12] Wendlandt, S., Kadlec, K., Feßler, A.T., Monecke, S., Ehricht, R., van de Giessen, A.W., Hengeveld, P.D., Huijsdens, X., Schwarz, S. and van Duijkeren, E. (2013) Resistance Phenotypes and Genotypes of Methicillin-Resistant Staphylococcus aureus Isolates from Broiler Chickens at Slaughter and Abattoir Workers. Journal of Antimicrobial Chemotherapy, 68, 2458-2463. http://dx.doi.org/10.1093/jac/dkt239

[13] Köck, R., Schaumburg, F., Mellmann, A., Köksal, M., Jurke, A., Becker, K. and Friedrich, A.W. (2013) Livestock Associated Methicillin-Resistant Staphylococcus aureus (MRSA) as Causes of Human Infection and Colonization in Germany. PLoS ONE, 8, e55040. http://dx.doi.org/10.1371/journal.pone.0055040

[14] Voss, A., Loeffen, F., Bakker, J., Klaassen, C. and Wulf, M. (2005) Methicillin-Resistant Staphylococcus aureus in Pig Farming. Emerging Infectious Diseases, 11, 1965-1966. http://dx.doi.org/10.3201/eid1112.050428

[15] Huss, H.H. (1988) Fresh Fish Quality and Quality Changes. FAO Fisheries Series, No. 29, FAO, Rome.

[16] Bryan, F.L. (1980) Foodborne Diseases in the United States Associated with Meat and Poultry. Journal of Food Protection, 43, 140-150.

[17] Beleneva, I.A. (2011) Incidence and Characteristics of Staphylococcus aureus and Listeria monocytogenes from the Japan and South China Seas. Marine Pollution Bulletin, 62, 382-387. http://dx.doi.org/10.1016/j.marpolbul.2010.09.024

[18] Hammad, A.M., Watanbe, W., Fujii, T. and Shimamoto, T. (2012) Occurrence and Characteristics of Methicillin Resistant and -Susceptible Staphylococcus aureus and Methicillin-Resistant Coagulase-Negative Staphylococci from Japanese Retail Ready-to-Eat Raw Fish. International Journal of Food Microbiology, 156, 286-289. http://dx.doi.org/10.1016/j.ijfoodmicro.2012.03.022 
[19] Vázquez-Sánchez, D., López-Cabo, M., Saá-Ibusquiza, P. and Rodríguez-Herrera, J.J. (2012) Incidence and Characterization of Staphylococcus aureus in Fishery Products Marketed in Galicia Northwest Spain. International Journal of Food Microbiology, 157, 286-296. http://dx.doi.org/10.1016/j.ijfoodmicro.2012.05.021

[20] Atyah, M.A., Zamri-Saad, M. and Siti-Zahrah, A. (2010) First Report of Methicillin-Resistant Staphylococcus aureus from Cage-Cultured Tilapia (Oreochromis niloticus). Veterinary Microbiology, 144, 502-504. http://dx.doi.org/10.1016/j.vetmic.2010.02.004

[21] FDA (Food and Drug Administration) (2004) Bacteriological Analytical Manual on Line. 8th Edition, Revision A, 1998 (Online). AOAC International, Arlington.

[22] CLSI (2008) Performance Standards for Antimicrobial Susceptibility Testing. 15th Informational Supplement, M100S15, Clinical and Laboratory Standards Institute, Wayne.

[23] Brakstad, O.G., Aasbakk, K. and Macland, J.A. (1992) Detection of Staphylococcus aureus by Polymerase Chain Reaction Amplification of nuc Gene. Journal of Clinical Microbiology, 30, 1654-1660.

[24] Oliveira, D.C. and de Lencastre, H. (2002) Multiplex PCR Strategy for Rapid Identification of Structural Types and Variants of the mec Element in Methicillin-Resistant Staphylococcus aureus. Antimicrobial Agents and Chemotherapy, 46, 2155-2161. http://dx.doi.org/10.1128/AAC.46.7.2155-2161.2002

[25] Xu, B., Liu, L. Liu, L., Li, X.P., Li, X.F. and Wang, X. (2012) A Multiplex PCR Assay for the Rapid and Sensitive Detection of Methicillin-Resistant Staphylococcus aureus and Simultaneous Discrimination of Staphylococcus aureus from Coagulase-Negative Staphylococci. Journal of Food Science, 77, 638-642. http://dx.doi.org/10.1111/j.1750-3841.2012.02959.x

[26] Abrahim, A., Sergelidis, D., Kirkoudis, I., Anagnostou, V., Kaitsa-Tsiopoulou, E., Kazila, P. and Papa, A. (2010) Isolation and Antimicrobial Resistance of Staphylococcus spp. in Freshwater Fish and Greek Marketplaces. Journal of Aquatic Food Product Technology, 19, 93-102. http://dx.doi.org/10.1080/10498850.2010.491597

[27] Ayulo, A.M.R., Machado, R.A. and Scussel, V.M. (1994) Enterotoxigenic Escherichia coli and Staphylococcus aureus in Fish and Seafood from the Southern Region of Brazil. International Journal of Food Microbiology, 24, 171-178. http://dx.doi.org/10.1016/0168-1605(94)90116-3

[28] Herrera, F.C., Santos, J.A., Otero, A. and García-López, M.-L. (2006) Occurrence of Foodborne Pathogenic Bacteria in Retail Prepackaged portions of Marine Fish in Spain. Journal of Applied Microbiology, 100, 527-536. http://dx.doi.org/10.1111/j.1365-2672.2005.02848.x

[29] Oh, S.K., Lee, N., Cho, Y.S., Shin, D.B., Choi, S.Y. and Koo, M. (2007) Occurrence of Toxigenic Staphylococcus aureus in Ready-to-Eat Food in Korea. Journal of Food Protection, 70, 1153-1158

[30] Rodma, P., Satjapala, T. and Suwanvitaya, P. (1991) Staphylococcus aureus Occurrence in Frozen Foods. Food, 21, 197-204.

[31] Sokari, T. (1991) Distribution of Enterotoxigenic Staphylococcus aureus in Ready-to-Eat Foods in Eastern Nigeria. International Journal of Food Microbiology, 12, 275-279. http://dx.doi.org/10.1016/0168-1605(91)90079-5

[32] Simon, S.S. and Sanjeev, S. (2007) Prevalence of Enterotoxigenic Staphylococcus aureus in Fishery Products and Fish Processing Factory Workers. Food Control, 18, 1565-1568. http://dx.doi.org/10.1016/j.foodcont.2006.12.007

[33] Normanno, G., Firinu, A., Virgilio, S., Mula, G., Dambrosio, A., Poggiu, A., Decastelli, L., Mioni, R., Sucuota, S., Bolzoni, G., Di Giannatale, E., Salinetti, A.P., La Salandra, G., Bartoli, M., Zuccon, F., Pirino, T., Sias, S., Parisi, A., Quaglia, N.C. and Celano, G.V. (2005) Coagulase-Positive Staphylococci and Staphylococcus aureus in Foods Products Marketed in Italy. International Journal of Food Microbiology, 98, 73-79. http://dx.doi.org/10.1016/j.ijfoodmicro.2004.05.008

[34] Zarei, M., Maktabi, S. and Ghorbanpour, M. (2012) Prevalence of Listeria monocytogenes, Vibrio parahaemolyticus, Staphylococcus aureus, and Salmonella spp. in Seafood Products Using Multiplex Polymerase Chain Reaction. Foodborne Pathogens and Disease, 9, 108-112. http://dx.doi.org/10.1089/fpd.2011.0989

[35] Hansen, L., Gill, T., Truelstrup, T. and Hussa, H.H. (1995) Effects of Salt and Storage Temperature on Chemical, Microbiological and Sensory Changes in Cold-Smoked Salmon. Food Research International, 28, 123-130. http://dx.doi.org/10.1016/0963-9969(95)90795-C

[36] Vilhelmsson, O., Hafsteinsson, H. and Kristjansson, J.K. (1997) Extremely Halotolerant Bacteria Characteristic of Fully Cured and Dried Cod. International Journal of Food Microbiology, 36, 163-170. http://dx.doi.org/10.1016/S0168-1605(97)01256-7

[37] Siriken, B., Yildirim, T., Erol, I., Durupinar, B., Çiftci, A. and Onuk, E.E. (2013) Prevalence and Characterization of Coagulase Positive Staphylococci Isolated from Salted Anchovy. Journal of Aquatic Food Product Technology, 22, 339-352. http://dx.doi.org/10.1080/10498850.2011.651773

[38] Basti, A.A., Misaghi, A., Salehi, T.Z. and Kamkar, A. (2006) Bacterial Pathogens in Fresh, Smoked and Salted Iranian Fish. Food Control, 17, 183-188. http://dx.doi.org/10.1016/j.foodcont.2004.10.001 
[39] Jay, J.M., Loessner, M.J. and Golden, D.A. (2005) Modern Food Microbiology. 7th Edition, Springer, New York.

[40] Arkoudelos, J.S., Samaras, F.J. and Tassou, C.C. (2003) Survival of Staphylococcus aureus and Salmonella enteritidis on Salted Sardines (Sardinapilchardus) during Ripening. Journal of Food Protection, 66, 1479-1481

[41] Vannuffel, P., Gigi, J., Ezzedine, H., Vandercam, B., Delmee, M., Wauters, G. and Gala, J.L. (1995) Specific Detection of Methicillin-Resistant Staphylococcus Species by Multiplex PCR. Journal of Clinical Microbiology, 33, 28642867.

[42] Barbier, F., Ruppé, E., Hernandez, D., Lebeaux, D., Francois, P., Felix, B., Desprez, A., Maiga, A., Woerther, P.L., Gaillard, K., Jeanrot, C., Wolff, M., Schrenzel, J., Andremont, A. and Ruimy, R. (2010) Methicillin-Resistant Coagulase-Negative Staphylococci in the Community: High Homology of SCCmecIVa between Staphylococcus epidermidis and Major Clones of Methicillin-Resistant Staphylococcus aureus. The Journal of Infectious Diseases, 202, 270-281. http://dx.doi.org/10.1086/653483

[43] Karchmer, A.W. (2000) Nosocomial Bloodstream Infections: Organisms, Risk Factors, and Implications. Clinical Infectious Diseases, 31, S139-S143. http://dx.doi.org/10.1086/314078

[44] Morgan, M. (2008) Methicillin-Resistant Staphylococcus aureus and Animals: Zoonosis or Humanosis? Journal of Antimicrobial Chemotherapy, 62, 1181-1187. http://dx.doi.org/10.1093/jac/dkn405

[45] García-Álvarez, L., Holden, M.T., Lindsay, H., Webb, C.R., Brown, D.F., Curran, M.D., Walpole, E., Brooks, K., Pickard, D.J., Teale, C., Parkhill, J., Bentley, S.D., Edwards, G.F., Girvan, E.K., Kearns, A.M., Pichon, B., Hill, R.L., Larsen, A.R., Skov, R.L., Peacock, S.J., Maskell, D.J. and Holmes, M.A. (2011) Methicillin-Resistant Staphylococcus aureus with a Novel mecA Homologue in Human and Bovine Populations in the UK and Denmark: A Descriptive Study. The Lancet Infectious Diseases, 11, 595-603. http://dx.doi.org/10.1016/S1473-3099(11)70126-8

[46] Suzuki, E., Hiramatsu, K. and Yokota, T. (1992) Survey of Methicillin-Resistant Clinical Strains of Coagulase Negative Staphylococci for mecA Gene Distribution. Antimicrobial Agents and Chemotherapy, 36, 429-434. http://dx.doi.org/10.1128/AAC.36.2.429

[47] Banerjee, R., Gretes, M., Harlem, C., Basuino, L. and Chambers, H.F. (2010) AmecA-Negative Strain of Methicillin-Resistant Staphylococcus aureus with High-Level $\beta$-Lactam Resistance Contains Mutations in Three Genes. Antimicrobial Agents and Chemotherapy, 54, 4900-4902. http://dx.doi.org/10.1128/AAC.00594-10

[48] Duran, N., Ozer, B., Duran, G.G., Onlen, Y. and Demir, C. (2012) Antibiotic Resistance Genes and Susceptibility Patterns in Staphylococci. Indian Journal of Medical Research, 135, 389-396

[49] Rhee, C.H. and Woo, G.J. (2010) Emergence and Characterization of Foodborne Methicillin-Resistant Staphylococcus aureus in Korea. Journal of Food Protection, 73, 2285-2290.

[50] Kumar, S. and Varela, M.F. (2012) Biochemistry of Bacterial Multidrug Efflux Pumps. International Journal of Molecular Sciences, 13, 4484-4495. http://dx.doi.org/10.3390/ijms13044484

[51] Piddock, L.J. (2006) Multidrug-Resistance Efflux Pumps? Not Just for Resistance. Nature Reviews Microbiology, 4, 629-636. http://dx.doi.org/10.1038/nrmicro1464

[52] Floyd, J.L., Smith, K.P., Floyd, J.T., Kumar, S. and Manuel, F.V. (2010) LmrS Is a Multidrug Efflux Pump of the Major Facilitator Superfamily from Staphylococcus aureus. Antimicrobial Agents and Chemotherapy, 54, 5406-5412. http://dx.doi.org/10.1128/AAC.00580-10 